\title{
Sustainability Management of Solid Waste in Tripoli Lebanon Landfill
}

\author{
Rida Tadmouri $^{1}$, Hamdi Sief $^{2}$ \\ ${ }^{1,2}$ Beirut Arab University, Engineering Department, Lebanon
}

\begin{abstract}
Municipal waste management is an important component of ecosystem and one of the essential part in sustainable development. This paper analyzes Tripoli landfill's situation. According to Municipality of Tripoli, the average production of waste reached 148.5 million in 2015 where all of these waste was dumped in north of the city which leads to many environmental and health crises. The maximum height point in the landfill reached $30 \mathrm{~m}$ in 2013 which is more than acceptable engineered height. The paper took Tripoli landfill as case study to account for the amount of economic and environmental benefits if it is subjected to around zero waste management. The study takes into account the waste generated in 2015 till 2065 by assuming $1.5 \%$ growth in population. As a result lots of economical, healthful and environmental benefits can be extracted if the generated waste is subjected to composting, recycling, reuse and incineration instead of throwing them.
\end{abstract}

\section{Introduction}

Solid waste management should be convenient with the nature of a given society, taking into account all activities and action required to manage waste from its origin to its final disposal. It is destined to reduce counteractive effects of waste on health, environment or aesthetics. This includes amongst other things, collection, transport, treatment and disposal of waste together with monitoring and regulation. It also comprises the sustainability issues; mainly through the integration of 3R (reduce, reuse and recycle) technologies. Nevertheless, degree and nature of improvements toward sustainability are varying which depends on the economic status of a country.

Managing waste at landfill sites is a meticulous job. Individuals should sort their garbage and recycle wherever possible. Composting and recycling are very useful in the reduction of solid waste. Self-serve landfill sites often have a place for people to put their hazardous waste, glass recycling, newspapers, metal recycling as well as old appliances, tires and other goods. Improper solid waste management leads to ample negative environmental influences (for example, air, soil and water pollution, green gas generation).

The troubles has been intensified by lack of effective legislation, insufficient funds, scant services, and inability of municipal authorities to deliver the services cost-efficiently.

\section{Current Situation of Solid Waste in Lebanon}

Lebanon has a population of 6.09 million people in 2018 of whom about 416,600 Palestinian refugees that produces 2,040,000 tons of Municipal Solid Waste (MSW) per year as reported by Worldometer. While the composition of the wastes is in majority organic as illustrated in Figure 1.

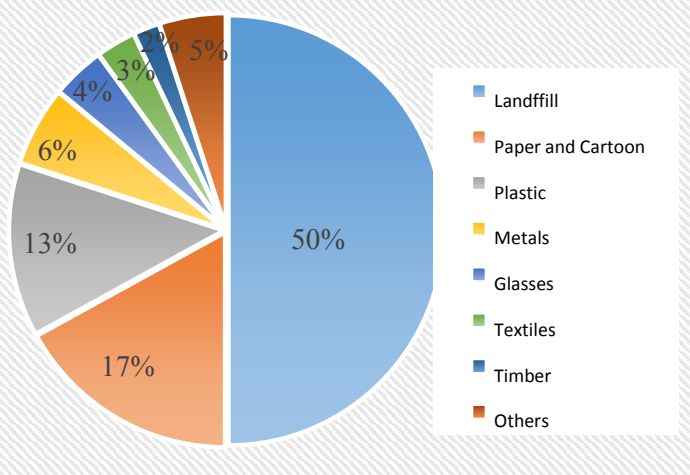

Figure. 1. Composition of Solid Waste in Lebanon 
Waste management varies from one area to another where $8 \%$ undergo to recycling, $15 \%$ to composting, $48 \%$ thrown in the landfill and $29 \%$ openly dumped [3].

\section{Case study}

\subsection{Description of the Study}

This section shows the economic study of sustainability solid waste management in Tripoli. The study covers 50 years. The number of residents in Tripoli (major) living there is almost 800 thousand people in 2014 [3]. The population growth rate is accounted by $0.98 \%$ per year. While $1.5 \%$ growth rate is taken to be in safe side to account for amount of waste generation after 50 years.

According to report done by Dar Al Handaseh Nasih Taleb and his Partners, the amount of waste generated from year 2000 till 2014 has been is $146,270,639 \mathrm{~kg}$. The yearly amount of waste that was generated and will expected to be generated till 2065 is shown Figure 2.

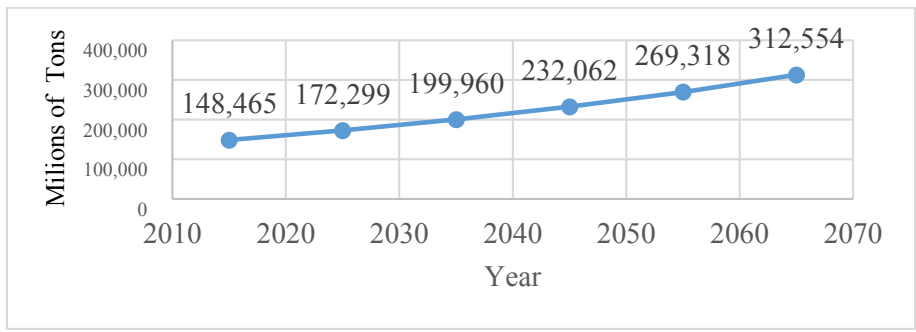

Figure. 2. Yearly production of waste in Tons from 2015 to 2065

According to study done by [4], there is $55 \%$ organic waste that could be converted to composite material and leads to soil improvement, the other $40 \%$ could be subjected to recycling. The remaining $5 \%$ of high colorific value that unable exposed to incineration that will produce heat, electricity, and power and enable citizen to be supplied with electricity all day. That is mean converting waste into new products that will preserve natural resources.

\subsection{Composting Economic Study}

\subsubsection{Composting Cost}

According to Lebanese mark, each bag of composite $(50 \mathrm{~kg})$ will cost between $90.0 \$$ to $181.8 \$$ depending on percent of nitrogen. To account for needed infrastructure, transport and labor's wages, $131.78 \$$ was taken. Tripoli landfill, has $55 \%$ of its constituent could be subjected to compositing which is equivalent to $(81,656 \mathrm{~T})$ in 2015 . Figure 3 shows the yearly composting cost from 2015 to 2065 .

\subsubsection{Composting Revenue}

According to Lebanon Seaboard Corporation Green View No.10 Fairway Formula Seed accelerator the unit price of fertilizer bag is around $150 \$$ dollars. If Tripoli's organic waste is composted, the return will be 244,966,753 Us Dollar in 2015 that will reach 515,714,400\$ in 2065. Figure 3 shows yearly income from 2015 to 2065 .

\subsubsection{Net Composting Revenue}

Net revenue for compositing cost is shown in Figure 3, where the income is 29.755 million dollar in 2015 that will be 62.64 million dollar in 2065 . 


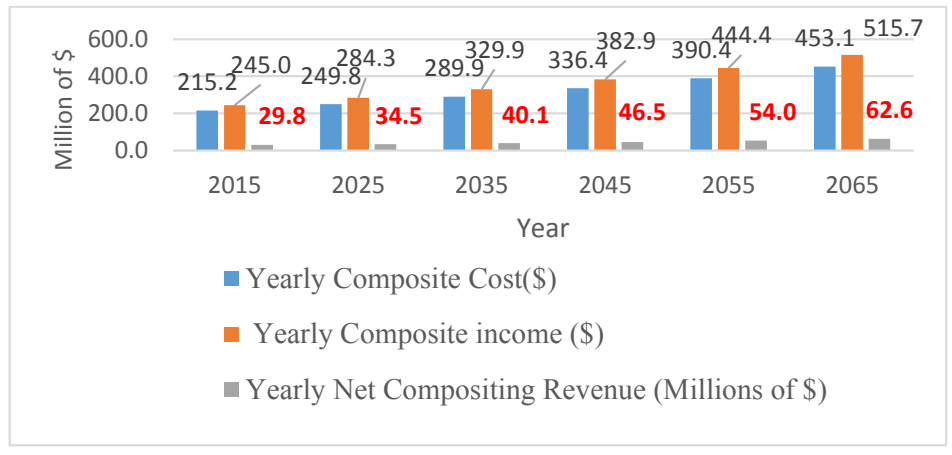

Figure. 3. Yearly composite cost, income and net revenue (Millions of \$)

\subsection{Recycling Economic Study}

\subsubsection{Recycling cost}

A recent journal article was published in the comments section of the Journal of Economic Perspectives that the minimum cost needed for recycle waste is $75 \$$ per ton of waste [5].

In this study, $100 \$$ per ton was taken as cost needed to recycle waste taking into consideration price of recycling machine, fuel, waste cleaning, different types of recycled items and labor's wage. Figure 4 shows that 5.9 million dollars recycling cost in 2015 that will be 12.5 million dollar in 2065 .

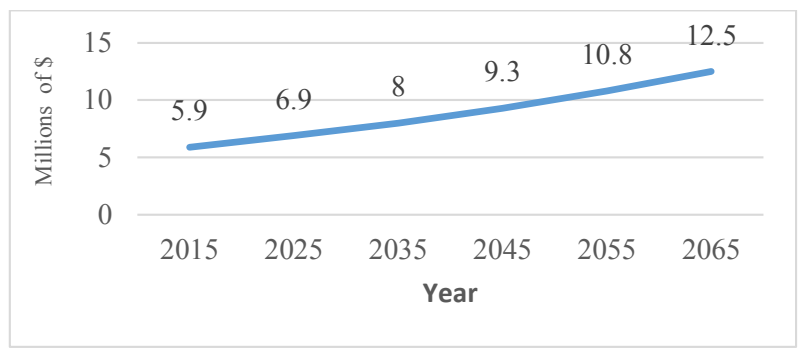

\subsubsection{Recycling Revenue}

Figure. 4. Yearly Recycling Cost Million \$

According to study done by letsrecycle, the price of different types of paper is ranging from 40 Euro per ton for mixed paper to 180 Euro per Ton for white paper recorded in February 2016. In this study 110 Euro per Ton was taken to account for labor Lebanese wages and other Lebanese considerations.

While the price of glass is ranging between 7 Euros per Ton to 25 Euro per ton in February 2016 according to different glass color .In this study 15 Euro per Ton was considered.

The price of glass is ranging between 7 Euros per Ton to 25 Euro per ton in February 2016 according to different glass color .In this study 15 Euro per Ton was considered.

For plastic, prices are ranging between 70 Euros per Ton for clear blue PET to 350 Euro per Ton for HDPE natural that are recorded in February 2016. In this study, 210 Euro per Ton was taken as average.

For textile, the prices differ according to the textile 'source. The price is ranging from 150 Euro per Ton for textile that comes from textile banks to 480 Euro per Ton for textile coming from sorting. As an average 300 Euro per Ton was taken. For metal, the price is ranging from 15 Euro per Ton to 25 Euro per Ton in February 2016. In this study, 20 Euro per Ton was considered.

For timber, the price is around 40 Euro per Ton for low to 67 Euro per Ton for high grade, 50 Euro per Ton was taken into consideration.

According to the data collected, if the recycle waste are replaced by new product instead of disposing them in the landfill, lots of benefits could be gained. Table 1 shows the Recycling revenue among different types of recycle materials in 2015 . Table 1 shows the recycling revenue among different type of recycle waste in 2065 , where the total revenue is $15,612,072 \$$ which is equivalent to 15.61 million dollar.

Table. 1. Recycling Revenue in 2065 


\begin{tabular}{|c|c|c|c|c|c|c|c|}
\hline & $\begin{array}{l}\text { Paper and } \\
\text { Cartoon } \\
15 \%\end{array}$ & Plastic $10 \%$ & $\begin{array}{l}\text { Metals } \\
\text { and } \\
\text { Metals } \\
\text { Bottles } \\
5 \%\end{array}$ & $\begin{array}{l}\text { Glasses } \\
3 \%\end{array}$ & Textile $3 \%$ & Timber $4 \%$ & Total $(\$)$ \\
\hline $\begin{array}{l}\text { price per } \\
\text { Ton }\end{array}$ & 110 & 210 & 20 & 15 & 300 & 50 & \\
\hline $\begin{array}{l}\text { weight in } \\
\text { Ton }\end{array}$ & 46883.1 & 31255.4 & 15627.7 & 9376.62 & 9376.62 & 12502.16 & \\
\hline $\operatorname{price}(\$)$ & $5,157,141$ & $6,563,634$ & 312,554 & 140,649 & $2,812,986$ & 625,108 & $15,612,072$ \\
\hline
\end{tabular}

\subsubsection{Net Recycling Revenue}

The net benefit of recycling is the difference between the costs needed to recycle waste and revenue that comes from selling items instead of buying them. After converting $40 \%$ from the total amount of waste into recycle items, the net revenue that comes from recycling waste is $1,477,227 \$$ which is equivalent to 1.47 million $\$$ in 2015 . The net revenue will increase with the increase of waste generation that leads to reach $3,109,912 \$$ in 2065 . Figure 5 shows yearly net recycling revenue.

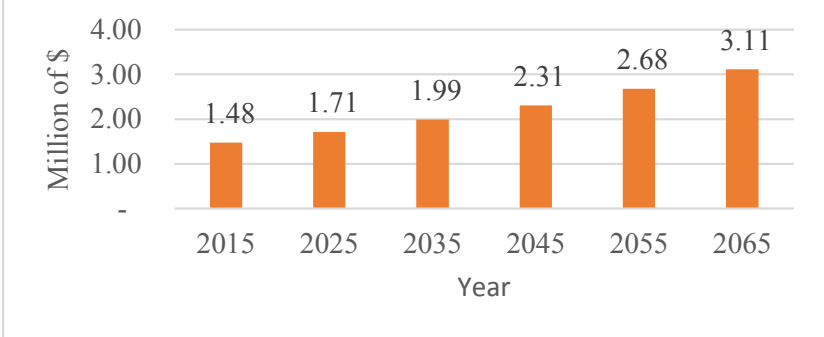

Figure. 5. Yearly Net Recycling Revenue \$

\subsection{Incineration economic study}

\subsubsection{Incineration cost}

The yearly operational cost comprises the utility costs (water, electricity, and gas), human resource costs, include cost of materials desired for air pollution control, cost of extra fuel when needed, cost of office maintenance, and other administrative costs. So the average cost is equivalent to $15.5 \$ /$ ton which is based on the data available in a recent feasibility study of a waste incinerator investment in the city of Baoji [6], supposing same incinerator characteristics will be used regardless of some difference in prices between countries.

Figure 6 shows the total cost needed to incinerate the remaining 5\% of Tripoli Waste. Where it needs $115,056.5 \$$ in 2015 and it will reach $242,234 \$$ in 2065 .

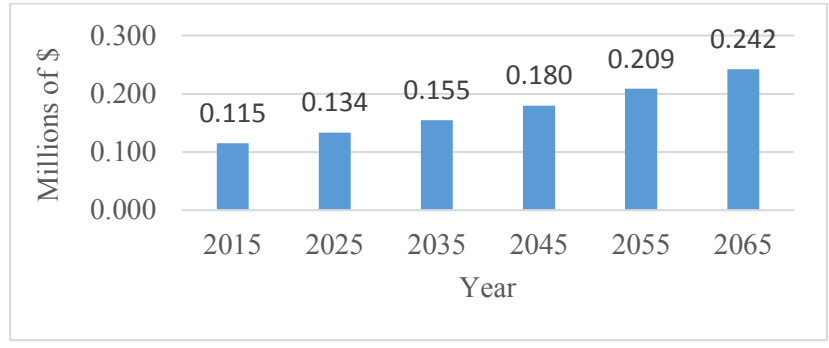

Figure. 6. Incineration Cost $\$$

\subsubsection{Incineration Revenue}

The energy content of waste is measured in terms of its colorific value (CV Expressed as Joules per Kilogram). 
To determine the energy generated from incinerator, we should take into consideration that there is for each type of waste, its caloric value that produce specific energy. To be on the safe side, we will take the average calorific value that is usually supposed to be between from $6 \mathrm{Mj} / \mathrm{kg}$ to $10 \mathrm{Mj} / \mathrm{kg}$. So the power generated from $8.5 \mathrm{Mj} / \mathrm{kg}$ (calorific value) is $0.8 \mathrm{Mwh} / \mathrm{T}$. According to Lebanese Ministry of Power and Electricity, the price of each $1 \mathrm{kwh}$ is 71 Lebanese L. The return from incinerating waste is $278,273.424 \$$ in 2015 and 585,862.464 \$ in 2065 as shown in Table 2.

Table. 2. Yearly Incineration Revenue \$

\begin{tabular}{|r|r|r|r|r|r|}
\hline Year & $\begin{array}{l}\text { Amount of } \\
\text { Waste per } \\
\text { Ton } 5 \%\end{array}$ & $\begin{array}{l}\text { Average calorific } \\
\text { value }(\mathrm{Kj} / \mathrm{kg})\end{array}$ & $\begin{array}{l}\text { Equivalent } \\
\text { Power MWh/t }\end{array}$ & $\begin{array}{l}\text { Electricity for } \\
\text { Sale MWh }\end{array}$ & $\begin{array}{l}\text { Equivalent Price of } \\
\text { electricity } \\
\text { generated per } \\
\text { year(Millions of \$) }\end{array}$ \\
\hline 2015 & 7,423 & 8.5 & 0.8 & 5938.4 & 0.278 \\
\hline 2025 & 58,61 & 8.5 & 0.8 & 6892 & 0.323 \\
\hline 2035 & 9,998 & 8.5 & 0.8 & 7998.4 & 0.375 \\
\hline 2045 & 11,603 & 8.5 & 0.8 & 9282.4 & 0.435 \\
\hline 2055 & 13,466 & 8.5 & 0.8 & 10772.8 & 0.505 \\
\hline 2065 & 15,628 & 8.5 & 0.8 & 12502.4 & 0.586 \\
\hline
\end{tabular}

\subsubsection{Net Incineration Revenue}

The net revenue can be calculated based on the estimated costs and potential income from sale of energy. Using the preconditions stated in the previous sections, Figure 7 shows incineration revenue from 2015 to 2065.

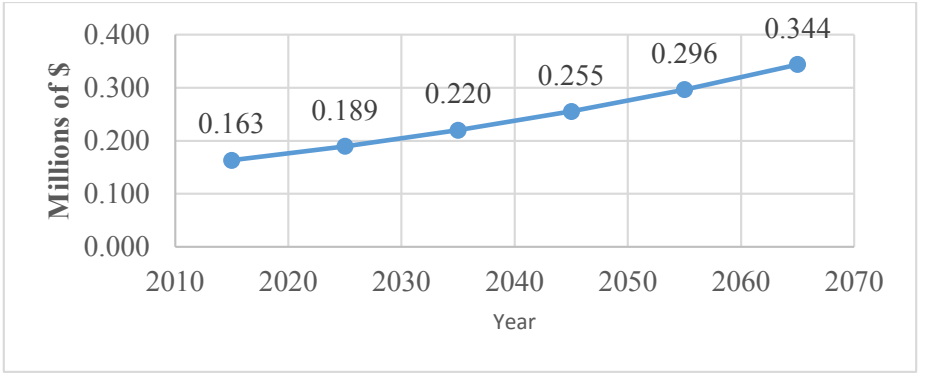

Figure. 7. Yearly Net Incineration Revenue Million \$

\section{Conclusion}

According to study done on Tripoli landfill, it shows that if municipality use waste in generating energy and reusing waste either as composite material or recycled one, there is a huge net revue concerning economy and health .The economic revenue is from offering new job in incineration plant or recycling factories in addition to replacing the immense use of natural resource to reusing it. There is 29.79 million $\$$ revenue from compositing, 1.47 million $\$$ from recycling and 0.1632 million $\$$ from incineration in year 2015. The net revenue will increase with the increase of waste generation to reach 62.64 million $\$$ in 2065 from composting, 3.1 million \$ from recycling and 0.34 million from incineration.

\section{References}

1. Worldometers. Lebanon population (2016).

2. The regional solid waste exchange of information and expertise network in mashreq and Maghreb countries (2014).

3. Rafai, A. Amer Al Refai presidence of municipality of Tripoli (2014).

4. Sabbagh, B. SWEEP-Net national coordinator (2014).

5. Dikgraaf E, G. R. Journal of economic perspective (2008).

6. Anonymous, Feasibility Report of A Municipal Solid Waste Incineration Plant (2004). 